Jurnal Kesehatan Karya Husada, No 7 Vol 2 Tahun 2019

PISSN 2337649X/EISSN 2655-8874

Siti Mahmudah "Pemanfaatan Sirup Buah Naga Merah (Hylocereus Polyrhizus) Untuk Meningkatkan Kadar

Hemoglobin" (hal 215-229)

Received

Revisied

10 Desember 2018

20 Februari 2019

Acceptep

16 Juni 2019

\title{
PEMANFAATAN SIRUP BUAH NAGA MERAH (HYLOCEREUS POLYRHIZUS) UNTUK MENINGKATKAN KADAR HEMOGLOBIN
}

\author{
1 Siti Mahmudah \\ Politeknik Kesehatan Karya Husada Yogyakarta \\ Email : sitimahmudah2000@yahoo.co.id
}

\begin{abstract}
ABSTRAK
Latar Belakang :Anemia merupakan masalah kesehatan pada wanita lanjut usia yang sering terabaikan dengan penyebab tersering adalah anemia akibat penyakit kronik dan defisiensi besi. Gejala anemia sering dianggap akibat usia yang lanjut dan kemampuan fisik yang menurun. Buah naga merah kaya kandungan zat besi sebagai penyusun utama sel darah merah sehingga mampu mencegah dan mengatasi anemia. Sirup buah merupakan cara praktis dalam mengkonsumsi buah Naga Merah sehingga kadar hemoglobin dapat meningkat. Tujuan Penelitian : untuk mengetahui manfaat sirup buah Naga Merah (Hylocereus Polyrhizus) untuk meningkatkan kadar Hemoglobin. Metode : Desain penelitian quasi eksperiment menggunakan non equivalent (pretest dan posttest) control group design. Sampel penelitian wanita pra lansia dan lansia Dusun Nangsri Pundong Bantul sejumlah 24 responden kelompok perlakuan dan kontrol. Teknik purposive sampling, pengujian hipotesis menggunakan Paired Samples T test dan uji Independent Samples $\mathrm{T}$ test. Hasil Penelitian : didapatkan rerata kadar Hemoglobin pada kelompok perlakuan meningkat $1 \mathrm{mg} / \mathrm{dl}$ sedangkan pada kelompok kontrol terdapat penurunan kadar Hemoglobin 1,02 mg/dl dengan $\rho$ value $0,034<$ alpha 0,05 sehingga ada perbedaan yang signifikan antara rerata kadar Hemoglobin sebelum dan sesudah pemberian sirup buah Naga Merah. Kesimpulan : konsumsi sirup buah Naga Merah $250 \mathrm{mg} /$ hari selama 7 hari bermanfaat untuk meningkatkan kadar Hemoglobin pada wanita pra lansia dan lansia.
\end{abstract}

Kata kunci : Buah Naga Merah, Hemoglobin

\section{ABSTRACT}

Background: Anemia is a health problem in elderly women who are often overlooked with the most common causes are anemia due to chronic disease and iron deficiency. Symptoms of anemia are often thought to be due to advanced age and decreased 
Jurnal Kesehatan Karya Husada, No 7 Vol 2 Tahun 2019

PISSN 2337649X/EISSN 2655-8874

Siti Mahmudah "Pemanfaatan Sirup Buah Naga Merah (Hylocereus Polyrhizus) Untuk Meningkatkan Kadar Hemoglobin" (hal 215-229)

physical ability. Red dragon fruit is rich in iron as the main constituent of red blood cells so it can prevent and overcome anemia. Fruit syrup is a practical way to consume Red Dragon fruit so that hemoglobin levels can increase. Objective: The aim of the study was to determine the benefits of Red Dragon fruit syrup (Hylocereus Polyrhizus) to increase Hemoglobin levels. The quasi-experimental research designused non equivalent (pretest and posttest) control group design. Pre-elderly and elderly female research samples in Nangsri Pundong Bantul Hamlet were 24 respondents in the treatment and control groups. Purposive sampling technique, hypothesis testing using Paired Samples T test and Independent Samples T test. Results: The results showed that the average hemoglobin level in the treatment group increased by $1 \mathrm{mg} / \mathrm{dl}$ while in the control group there was a decrease in Hemoglobin level of $1.02 \mathrm{mg} / \mathrm{dl}$ with $\rho$ value of 0.034 <alpha 0.05 so there was a significant difference between the mean hemoglobin level before and after administration Red Dragon fruit syrup. Conclusion The consumption of Red Dragon fruit syrup $250 \mathrm{mg} /$ day for 7 days is useful for increasing Hemoglobin levels in pre-elderly women and the elderly.

Keywords: Red Dragon Fruit, Hemoglobin

\section{PENDAHULUAN}

Salah satu masalah kesehatan yang terjadi pada lansia yaitu anemia yang merupakan kelainan hematologi yang paling sering dijumpai pada lansia. Anemia bukanlah suatu kesatuan penyakit tersendiri (disease entity), tetapi merupakan gejala berbagai macam penyakit dasar (underlying disease). Anemia pada usia lanjut terkadang terabaikan karena gejalanya seringkali tidak sejelas anemia pada usia produktif. Gejala anemia yang khas seperti cepat lelah, merasa lemas, ataupun sesak nafas seringkali dianggap disebabkan oleh usia yang lanjut dan kemampuan fisik yang menurun. Anemia sering menjadi faktor pemberat pada penyakit yang diderita oleh usia lanjut. Penderita anemia memerlukan banyak asupan nutrisi yang memiliki kemampuan untuk mempercepat terjadinya proses pembentukan sel darah merah baru dan menambah hemoglobin. Khasiat ini bisa di dapatkan dari buahbuahan yang banyak mengandung asam folat dan zat besi. Buah Naga merah merupakan buah yang memiliki banyak sekali manfaat terutama untuk meningkatkan pembentukan sel darah merah/hemoglobin. Tujuan penelitian 
Jurnal Kesehatan Karya Husada, No 7 Vol 2 Tahun 2019

PISSN 2337649X/EISSN 2655-8874

Siti Mahmudah "Pemanfaatan Sirup Buah Naga Merah (Hylocereus Polyrhizus) Untuk Meningkatkan Kadar Hemoglobin" (hal 215-229)

untuk mengetahui manfaat sirupbuah Naga Merah (Hylocereus Polyrhizus) untuk meningkatkan kadar Hemoglobin pada wanita pra lansia dan lansia.

\section{METODE PENELITIAN}

Desain penelitian quasi eksperiment menggunakan non equivalent (pretest dan posttest) control group design.

Sampel penelitian adalah wanita pra lansia dan lansia Dusun Nangsri Pundong Bantul sejumlah 24 responden yang terdiri dari kelompok perlakuan dan kontrol. Teknik pengambilan sampel menggunakan purposive sampling. Penelitian dilakukan di Dusun Nangsri Desa Srihardono Pundong Bantul, sedangkan waktu pelaksanaan penelitian pada bulan September sampai November 2018. Instrument penelitian ini menggunakan format pengumpulan data dan alat pengukur kadar hemoglobin easy touch GCU. Prosedur pengumpulan data diawali dengan pemberian informed consent kemudian dilakukan pengambilan data dengan melakukan pemeriksaan kadar Hemoglobin menggunakan alat pengukur kadar hemoglobin easy touch
$G C U$ pada responden kelompok perlakuan maupun kelompok kontrol. Setelah pengambilan sampel darah diperoleh kemudian diberikan intervensi dengan pemberian sirup

buah Naga Merah Merah (Hylocereus Polyrhiruz) dengan dosis $250 \mathrm{ml}$ yang diminum satu hari sekali menjelang tidur malam selama 7 hari sedangkan pada kelompok kontrol tidak diberikan. Pengukuran kadar Hemoglobin dilakukan sebanyak dua kali yaitu sebelum pemberian sirup Buah Naga Merah dan sesudah 7 hari pemberian sirup Buah Naga Merah. Pembuatan sirup buah Naga

Merah diawali dengan pemilihan buah Naga Merah yang baik yaitu dipilih buah yang warnanya merata dan tidak terdapat memar / bercak, pelepah masih utuh dan lentur. Proses pembuatan sirup dapat dilakukan dengan cara buah yang matang optimal disortasi kemudian dicuci dan dikupas kemudian dihancurkan dan disaring. Ekstrak buah Naga Merah kemudian ditambahkan gula pasir dengan perbandingan 1:0,5 dan dipanaskan sampai mengental kemudian dimasukkan ke dalam botol yang telah disterilkan. pengolahan data 
Jurnal Kesehatan Karya Husada, No 7 Vol 2 Tahun 2019

PISSN 2337649X/EISSN 2655-8874

Siti Mahmudah "Pemanfaatan Sirup Buah Naga Merah (Hylocereus Polyrhizus) Untuk Meningkatkan Kadar Hemoglobin" (hal 215-229)

diawali dengan tabulasi, coding dan editing selanjutkan melakukan entry data. Analisis data menggunakan program IBM SPSS Statistics 22 yang meliputi analisis univariat dan bivariat. Uji statistik yang digunakan adalah Paired Samples t-test dan uji Independent t-test.

\section{HASIL}

Pengambilan data tahap I dan II dilakukan pada bulan Oktober 2018 dengan melakukan pengukuran kadar Hemoglobin pada wanita pra lansia dan lansia di Dusun Nangsri Srihardono Pundong Bantul.

Jumlah responden 24 responden yang terdiri dari 12 responden kelompok perlakuan dan 12 kelompok kontrol Data Karakteristik Responden sebagai berikut

\section{a. Distribusi Frekuensi Responden Menurut Umur}

\begin{tabular}{ccccccc} 
Variabel & \multicolumn{2}{c}{ Perlakuan } & \multicolumn{2}{c}{ Kontrol } & \multicolumn{2}{c}{ Total } \\
\hline Umur & $\mathrm{f}$ & $\%$ & $\mathrm{f}$ & $\%$ & $\mathrm{f}$ & $\%$ \\
\hline $45-50$ & 1 & 8,33 & 0 & 0,00 & 1 & 4,17 \\
\hline $51-55$ & 1 & 8,33 & 1 & 8,33 & 2 & 8,33 \\
\hline $61-65$ & 3 & 25,0 & 5 & 41,6 & 8 & 33,33 \\
\hline -65 & 7 & 58,3 & 6 & 50,0 & 13 & 54,17 \\
\hline Jumlah & 12 & 100 & 12 & 100 & 24 & 100 \\
\hline
\end{tabular}

Bersarkan tabel diatas dapat diketahui bahwa mayoritas responden berumur lenih dari 65 tahun yaitu 13 responden $(54,17 \%)$ dan sedangkan yang palingsedikit adalah responden yang berumur 56-60 tahun sejumlah 0 responden $(0 \%)$.

\section{b. Distribusi Frekuensi responden menurut paritas}

\begin{tabular}{ccccccc} 
Variabel & \multicolumn{2}{l}{ Perlakuan } & \multicolumn{2}{l}{ Kontrol } & \multicolumn{2}{l}{ Total } \\
\hline Paritas & $\mathrm{f}$ & $\%$ & $\mathrm{f}$ & $\%$ & $\mathrm{f}$ & $\%$ \\
\hline Primipara & 0 & 0 & 1 & 8,33 & 1 & 4,17 \\
\hline Sekundipara & 3 & 25,0 & 3 & 25,0 & 6 & 25,0 \\
\hline Multi para & 7 & 53,3 & 7 & 53,3 & 14 & 53,3 \\
\hline Grande & 2 & 16,7 & 1 & 8,33 & 3 & 12,50 \\
Multipara & & & & & & \\
\hline Jumlah & 12 & 100 & 12 & 100 & 24 & 100 \\
\hline
\end{tabular}

Bersarkan tabel diatas dapat diketahui bahwa mayoritas responden dengan paritas multipara yaitu 14 responden $(53,33 \%)$ dan sedangkan yang paling sedikit adalah responden primipara sejumlah 1 responden $(4,17 \%)$.

\section{c. Distribusi Frekuensi Responden Menurut Tingkat Pendidikan}

\begin{tabular}{ccccccc}
\hline $\begin{array}{c}\text { Variable } \\
\begin{array}{c}\text { Pendidi } \\
\text { kan }\end{array}\end{array}$ & $\begin{array}{c}\text { Perlakuan } \\
\text { f }\end{array}$ & $\%$ & Kontrol & \multicolumn{2}{c}{ Total } \\
\hline SD & 11 & $\$ 3,3$ & 11 & 83,3 & 20 & 83,3 \\
SMP & 1 & 8,3 & 1 & 8,3 & 2 & 8,3 \\
SMA & 1 & 8,3 & 1 & 8,3 & 1 & 4,17 \\
Jumlah & 12 & 100 & 12 & 100 & 24 & 100 \\
\hline
\end{tabular}


Jurnal Kesehatan Karya Husada, No 7 Vol 2 Tahun 2019

PISSN 2337649X/EISSN 2655-8874

Siti Mahmudah "Pemanfaatan Sirup Buah Naga Merah (Hylocereus Polyrhizus) Untuk Meningkatkan Kadar Hemoglobin" (hal 215-229)

Bersarkan tabel diatas dapat diketahui bahwa mayoritas responden dengan pendidikan SD yaitu 20 responden $(83,33 \%)$ dan sedangkan yang paling sedikit adalah responden SMA sejumlah 1 responden $(4,17 \%)$.

\section{d. Kadar Hemoglobin}

\begin{tabular}{cccccccccc}
\hline Kelompok & \multicolumn{9}{c}{ Kadar Asam Urat } \\
& \multicolumn{2}{c}{ Naik } & \multicolumn{2}{c}{ Turun } & \multicolumn{2}{c}{ Tetap } & \multicolumn{2}{c}{ Total } \\
& $\mathrm{f}$ & $\%$ & $\mathrm{f}$ & $\%$ & $\mathrm{f}$ & $\%$ & $\mathrm{f}$ & $\%$ \\
\hline Perlakuan & 12 & 100 & 0 & 0 & 0 & 0 & 12 & 100 \\
Kontrol & 2 & 16,67 & 9 & 75 & 1 & 8,33 & 12 & 100 \\
\hline
\end{tabular}

Bersarkan tabel diatas dapat diketahui bahwa seluruh responden pada kelompok perlakuan dengan kadar hemoglobin naik yaitu 12 responden (100\%) sedangkan pada kelompok kontrol mayoritas kadar hemoglobin turun yaitu sejumlah 9 responden $(75 \%)$ sedangkan yang paling sedikit adalah tetap dengan jumlah 1 responden $(8,33 \%)$.

\section{e. Hasil Uji Normalitas Data}

\begin{tabular}{cccccccc|}
\hline Kelompok & \multicolumn{6}{c|}{ Uji Normalitas Data } \\
& Kolmogorov-Smimov & \multicolumn{3}{c|}{ Shapiro-Wilk } \\
& Statistic & df & sig & Statistic & df & sig \\
\hline Perlakuan &, 129 & 12 &, $200^{*}$ &, 937 & 12 &, 455 \\
Kontrol &, 176 & 12 &, $200^{*}$ &, 933 & 12 &, 415 \\
\hline
\end{tabular}

Berdasarkan tabel diatas dapat diketahui bahwa uji Kolmogorov-Smirnov pada kelompok perlakuan didapatkan $p$ value 0,200 > alpha 0,05 dan pada kelompok kontrol dengan $p$-value 0,200 $>$ alpha 0,05. Sedangkan uji ShapiroWilk pada kelompok perlakuan didapatkan $p$-value 0,455 > alpha 0,05 dan pada kelompok kontrol dengan $p$ value 0,415 > alpha 0,05 sehingga pada kelompok perlakuan maupun kontrol data berdistribusi normal.

\section{f. Rerata Kadar hemoglobin Kelompok Perlakuan}

\begin{tabular}{ccccccc}
\hline Nomor & Kelompok & N & Mean & SD & Std. Error Mean & Sig. (2-tailed) \\
\hline 1 & Pre & 12 & 12,04 &, 998 &, 288 & \\
2 & Post & 12 & 13,04 &, 869 &, 251 & 0,000 \\
\hline
\end{tabular}

Berdasarkan Uji Paired Sample T Test dapat diketahui bahwa 12 responden kelompok Perlakuan mempuyai rerata kadar Hemoglobin pre tes $12,04 \mathrm{mg} / \mathrm{dL}$ dengan standar deviasi 0,998 dan Std. Error Mean 0,288 sedangkan untuk rerata kadar Hemoglobin post tes 13,04dengan standar deviasi 0,869 dan Std. Error Mean 0,251. Perbedaan rerata pada kelompok perlakuan pre dan post test didapatkan $p$ - value $0,000<$ alpha 0,05 sehingga terdapat perbedaan rerata 
Jurnal Kesehatan Karya Husada, No 7 Vol 2 Tahun 2019

PISSN 2337649X/EISSN 2655-8874

Siti Mahmudah "Pemanfaatan Sirup Buah Naga Merah (Hylocereus Polyrhizus) Untuk Meningkatkan Kadar Hemoglobin" (hal 215-229)

pada kelompok perlakuan yang tidak

mengkonsumsi sirup buah Naga Merah

selama 7 hari

g. Rerata Kadar hemoglobin

Kelompok Kontrol

\begin{tabular}{ccccccc|}
\hline Nomor & Kelompok & N & Mean & SD & Std. Error Mean & Sig. (2-tailed) \\
\hline 1 & Pre & 12 & 13,31 &, 375 &, 108 & \\
2 & Post & 12 & 12,29 &, 749 &, 216 & 0,001 \\
\hline
\end{tabular}

Berdasarkan Uji Paired Sample T Test dapat diketahui bahwa 12 responden kelompok Perlakuan mempuyai rerata kadar Hemoglobin pre tes $13,31 \mathrm{mg} / \mathrm{dL}$ dengan standar deviasi 0,375 dan Std. Error Mean 0,108 sedangkan untuk rerata kadar Hemoglobin post tes 12,29 dengan standar deviasi 0,749 dan Std. Error Mean 0,216. Perbedaan rerata pada kelompok perlakuan pre dan post test didapatkan p-value 0,001 < alpha 0,05 sehingga terdapat perbedaan rerata pada kelompok perlakuan yang tidak mengkonsumsi sirup buah Naga Merah selama 7 hari h. Uji Independen Samples T Test pada Kelompok Perlakuan dan Kontrol

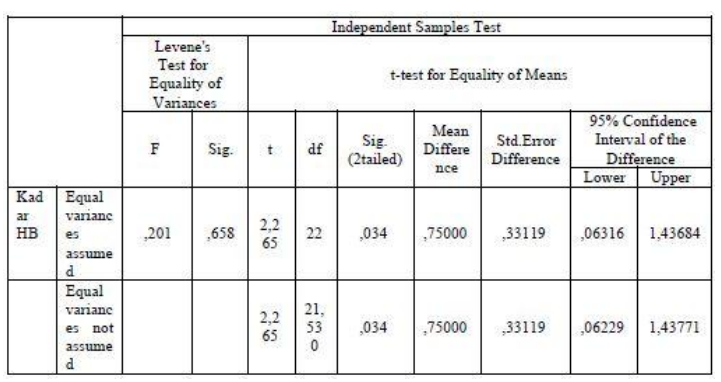

Berdasarkan Uji Independent Samples $T$ Test menggunakan IBM SPSS Statistics 22 pada kelompok perlakuan dan kontrol didapatkan nilai p-values 0.034 < Alpha 0,05 maka dinyatakan Ho ditolak sehingga terdapat perbedaan antara responden yang mengkonsumsi sirup buah Naga Merah (Hylocereus Polyrhiruz) dengan yang tidak mengkonsumsi sirup buah Naga Merah (Hylocereus Polyrhiruz). Dengan demikian terdapat perbedaan rerata kadar Hemoglobin yang signifikan antara responden yang mengkonsumsi sirup buah Naga Merah (Hylocereus Polyrhiruz) dan yang tidak mengkonsumsi sirup buah Naga Merah (Hylocereus Polyrhiruz).

\section{PEMBAHASAN}

Hemoglobin $(\mathrm{Hb})$ merupakan komponen sel darah merah yang berfungsi Page 220 | 
Jurnal Kesehatan Karya Husada, No 7 Vol 2 Tahun 2019

PISSN 2337649X/EISSN 2655-8874

Siti Mahmudah "Pemanfaatan Sirup Buah Naga Merah (Hylocereus Polyrhizus) Untuk Meningkatkan Kadar Hemoglobin" (hal 215-229)

menyalurkan oksigen ke seluruh tubuh.

Jika $\mathrm{Hb}$ berkurang, jaringan tubuh

kekurangan oksigen yang diperlukan tubuh untuk proses metabolisme. Menurut Manuaba (2001), hemoglobin adalah molekul protein pada sel darah merah yang berfungsi sebagai media transport oksigen dari paru-paru. Kandungan zat besi yang terdapat dalam hemoglobin membuat darah berwarna merah. Hemoglobin merupakan komponen dalam darah yang berfungsi sebagi alat transport dalam pertukaran gas oksigen dan karbondioksida. Apabila dalam tubuh seseorang mengalami kekurangan hemoglobin maka akan mengalami anemia. Anemia menyebabkan berkurangnya jumlah sel darah merah atau jumlah hemoglobin dalam sel darah merah, sehingga darah tidak dapat mengangkut oksigen dalam jumlah sesuai yang diperlukan tubuh . Fungsi utama hemoglobin adalah mengangkut oksigen dari paru-paru ke jaringan tubuh, sehingga memberikan energi untuk reaksi kimia dalam sel-sel hidup. Karbon dioksida, yang dilepaskan sebagai produk sampingan dari reaksi-reaksi kimia, dibawa kembali ke paru-paru untuk pernafasan. Kadar hemoglobin atau $\mathrm{Hb}$ seseorang dapat diketahui dengan melakukan pemeriksaan darah. Kekurangan hemoglobin menunjukkan adanya kondisi atau penyakit tertentu. Gejala dan tanda bahwa seseorang kekurangan $\mathrm{Hb}$ sangat bergantung pada penyakit penyerta yang mendasari munculnya gangguan ini. Tanda-tanda kekurangan hemoglobin adalah merasa lelah, lemah, pucat pada kulit dan gusi, sesak napas, detak jantung tidak teratur, dan kuning pada mata atau kulit. Kekurangan hemoglobin bisa saja tidak bergejala namun bisa juga menunjukkan gejala yang berat. Hal ini karena penyebabnya bisa bermacam-macam dan sangat bergantung pada penyakit penyerta atau kondisi yang mendasarinya. Keadaan di mana kadar $\mathrm{Hb}$ kurang dari nilai normal disebut sebagai Anemia. Anemia merupakan salah satu penyakit yang umum terjadi di Indonesia. Berdasarkan data WHO (World Health Organization) atau Badan Kesehatan Dunia dan juga data kesehatan Indonesia menunjukan bahwa negara Indonesia sebagai salah satu negara dengan kasus anemia terbanyak. Hal ini di sebabkan oleh sebagian besar penduduk Indonesia 
Jurnal Kesehatan Karya Husada, No 7 Vol 2 Tahun 2019

PISSN 2337649X/EISSN 2655-8874

Siti Mahmudah "Pemanfaatan Sirup Buah Naga Merah (Hylocereus Polyrhizus) Untuk Meningkatkan Kadar Hemoglobin" (hal 215-229)

yang mengalami kekurangan zat besi yang merupakan salah satu permasalahan nutrisi. Usia lanjut terutama pada perempuan adalah kelompok usia yang sering sekali terkena anemia. Mengingat seringnya kaum usia lanjut mengidap anemia, maka seringkali anemia dianggap wajar dan tidak mendapat perhatian. Padahal, kadar hemoglobin seharusnya tidak turun seiring dengan peningkatan usia pada orang yang tidak mengidap penyakit dan memiliki sumsum tulang yang normal. Anemia pada usia lanjut terkadang terabaikan karena gejalanya seringkali tidak sejelas anemia pada usia produktif. Gejala anemia yang khas seperti cepat lelah, merasa lemas, ataupun sesak nafas seringkali dianggap disebabkan oleh usia yang lanjut dan kemampuan fisik yang memang sudah menurun. Anemia kerap menjadi faktor pemberat pada penyakit yang diderita oleh kaum usia lanjut. Kondisi gagal jantung, gangguan kognitif, dan gangguan keseimbangan akan menjadi lebih berat karena anemia yang diderita. Namun, jika tidak diperiksa dengan teliti, keadaan memberatnya penyakit dasar seseorang seringkali dianggap disebabkan oleh hal lain dan bukan anemia. Penyebab tersering anemia pada kaum usia lanjut adalah anemia akibat penyakit kronik dan defisiensi besi. Peran hemoglobin dalam tubuh manusia sangat penting untuk menjalani hidup sehat yang sangat diperlukan untuk menjaga tingkat pigmen dalam darah. Sedikit variasi dari tingkat hemoglobin dari normal dapat tidak menimbulkan gejala yang nyata. Namun, variasi yang drastis dapat menyebabkan gejala yang parah, dan mengakibatkan komplikasi apabila tidak segera mendapat penanganan. Penanganan Anemia dapat di lakukan dengan mengkonsumsi suplemen penambah zat besi agar meningkatkan kadar kandungan zat besi pada tubuh. Asupan zat besi pada makanan-makanan yang di konsumsi juga harus di perhatikan dalam meningkatkan asupan zat besi. Untuk meningkatkan hemoglobin dalam darah, maka diperlukan makanan yang kaya akan zat besi. Buah Naga Merah kaya akan kandungan zat besi sebagai penyusun utama sel darah merah sehingga mampu mencegah dan mengatasi anemia. Zat besi yang ada pada buah Naga sangat baik dalam 
Jurnal Kesehatan Karya Husada, No 7 Vol 2 Tahun 2019

PISSN 2337649X/EISSN 2655-8874

Siti Mahmudah "Pemanfaatan Sirup Buah Naga Merah (Hylocereus Polyrhizus) Untuk Meningkatkan Kadar Hemoglobin" (hal 215-229)

meningkatkan kadar hemoglobin.

Berdasarkan hasil penelitian yang telah dilakukan dengan 24 responden wanita pra lansia dan lansia yang dibagi menjadi kelompok perlakuan dan kelompok kontrol dengan masingmasing kelompok sejumlah 12 responden. Pada awal penelitian dilakukan pemeriksaan kadar Hemoglobin pada 24 responden kelompok perlakuan dan kontrol. Pada kelompok perlakuan diberikan sirup buah Naga Merah (Hylocereus Polyrhiruz) dengan dosis $250 \mathrm{ml}$ yang diminum satu hari sekali menjelang tidur malam selama 7 hari sedangkan pada kelompok kontrol tidak diberikan.

Pada kelompok perlakuan semua mengalami kenaikan kadar Hemoglobin $100 \%$ sedangkan pada kelompok kontrol kadar Hemoglobin yang mengalami kenaikan sejumlah $16,67 \%$, yang kadarnya tetap sejumlah $8,33 \%$, dan yang kadarnya turun sebanyak $75 \%$. Hasil uji Paired Samples $T$ Test menunjukkan bahwa 12 responden kelompok perlakuan mempunyai nilai rerata kadar Hemoglobin pre test 12,04 mg/dl dengan Standar Deviasi 0,998, Std. Error Mean 0,228 sedangkan untuk rerata kadar Hemoglobin post test 13,04 $\mathrm{mg} / \mathrm{dl}$ dengan Standar Deviasi 0,869, Std. Error Mean 0,251. Perbedaan rerata pada kelompok perlakuan didapatkan $p$ value $0,000<$ alpha 0,05 sehingga terdapat perbedaan pada kelompok perlakuan yang mengkonsumsi sirup buah Naga Merah (Hylocereus Polyrhiruz) selama 7 hari. Pada responden kelompok perlakuan didapatkan rerata kadar Hemohlobin 13,04 mg/dl meningkat dibandingkan saat pemeriksaan pre test yaitu 12,04 $\mathrm{mg} / \mathrm{dl}$ dengan peningkatan $1 \mathrm{mg} / \mathrm{dl}$. Pada kelompok kontrol rerata kadar Hemoglobin pre test $13,31 \mathrm{mg} / \mathrm{dl}$ dengan Standar Deviasi 0,375, Std. Error Mean 0,108 sedangkan untuk rerata kadar Hemoglobin post test 12,29 dengan Standar Deviasi 0,749, Std. Error Mean 0,216. Perbedaan rerata pada kelompok kontrol pre dan post test didapatkan $p$-value $0,001<$ alpha 0,05 sehingga terdapat perbedaan rerata kadar Hemoglonin pada kelompok kontrol yang tidak mengkonsumsi sirup buah Naga Merah (Hylocereus Polyrhiruz) selama 7 hari. Pada responden kelompok kontrol rerata kadar Hemoglobin 12,29 $\mathrm{mg} / \mathrm{dl}$ 
Jurnal Kesehatan Karya Husada, No 7 Vol 2 Tahun 2019

PISSN 2337649X/EISSN 2655-8874

Siti Mahmudah "Pemanfaatan Sirup Buah Naga Merah (Hylocereus Polyrhizus) Untuk Meningkatkan Kadar Hemoglobin" (hal 215-229)

menurun dibandingkan saat pemeriksaan pre test yaitu 13,31 mg/dl dengan penurunan $1,02 \mathrm{mg} / \mathrm{dl}$.

Hemoglobin $(\mathrm{Hb})$ merupakan salah satu dari suatu bentuk protein yang terdapat pada sel darah merah atau eritrosit. Sel darah merah itu sendiri berperan sangat penting untuk keberlangsungan sistem metabolisme tubuh, hemoglobin memiliki peran untuk membawa oksigen dari paruparu ke seluruh bagian tubuh kemudian mendistribusikan karbondioksida untuk dikeluarkan dari tubuh. Hemoglobin merupakan komponen pigmen yang mempunyai kandungan zat besi yang tinggi dan memiliki tugas dalam mengikat oksigen serta sebagai sarana transportasi ke seluruh tubuh. Melakukan pemeriksaan kadar Hemoglobin secara rutin sangat penting dilakukan guna mengetahui sejauh mana kadar Hemoglobin dalam kisaran normal atau tidak dan segera melakukan tindakan pengobatan jika diperlukan. Jika kadar Hemoglobin lebih rendah dari ukuran normal, menandakan bahwa kadar oksigen dalam darah juga cukup rendah, yang akan berdampak pada gangguan

kesehatan. Penyebab yang paling umum ketika seseorang kekurangan Hemoglobin adalah kurangnya gizi pada tubuh. Dengan pola makan yang sehat, terlebih dengan banyak mengkonsumsi berbagai macam sayuran akan membuat Hemoglobin anda cepat meningkat. Dapat juga ditambah dengan memakan beberapa suplemen yang banyak mengandung zat besi dan juga kalsium dapat mengurangi turunnya kadar Hemoglobin. Kadar hemoglobin atau $\mathrm{Hb}$ seseorang dapat diketahui dengan melakukan pemeriksaan darah. Kekurangan hemoglobin bisa jadi menunjukkan adanya kondisi atau penyakit tertentu. Gejala dan tanda bahwa seseorang kekurangan $\mathrm{Hb}$ sangat bergantung pada penyakit penyerta yang mendasari munculnya gangguan ini. Buah Naga Merah (Hylocereus Polyrhizus) adalah salah satu buah yang banyak dinikmati oleh masyarakat luas. Buah naga termasuk buah yang paling mudah dikenali karena bentuknya yang unik. Tanaman buah naga termasuk dalam keluarga tanaman kaktus, di mana tanaman jenis ini dapat hidup di lingkungan yang kekurangan air sekalipun. Tanaman ini memiliki duri- 
Jurnal Kesehatan Karya Husada, No 7 Vol 2 Tahun 2019

PISSN 2337649X/EISSN 2655-8874

Siti Mahmudah "Pemanfaatan Sirup Buah Naga Merah (Hylocereus Polyrhizus) Untuk Meningkatkan Kadar Hemoglobin" (hal 215-229)

duri tajam, batangnya berbentuk segitiga, tumbuh merambat, dan memiliki lapisan lilin di pohonnya. Sebagian besar masyarakat mengenal buah Naga Merah hanya terbatas pada rasanya yang manis, kandungan airnya yang menyegarkan, serta kenikmatannya pada saat dijadikan sebagai bahan campuran minuman dingin. Diluar itu tak banyak yang memahami akan kandungan manfaat buah naga merah untuk kesehatan. Buah Naga Merah memiliki tampilan luar yang sangat unik yaitu dengan kulit berwarna merah yang menyerupai bentuk api yang menyala. Bagian dalam buah ini juga berwana merah keunguan, memiliki kadar air yang cukup tinggi, dan berbiji lunak. Tekstur buah di dalamnya hampir menyerupai buah kiwi. Kulit buah naga berlapis-lapis menyerupai sisik naga, sehingga buah ini dinamai buah naga. Buah Naga Merah juga memiliki banyak kandungan nutrisi yang begitu besar bagi kesehatan tubuh. Nutirisi yang terkandung didalam buah naga merah ini adalah karbohidrat, magnesium, fosfor, zat besi, protein, senyawa antioksidan, vitamin B1,B2,B3,B12, dan Vitamin C. Buah naga ini mempunyai rasa yang lezat dan menyegarkan. Kandungan antioksidan serta vitamin yang terdapat dalam buah naga merah dapat memberikan manfaat dalam menjaga kesehatan serta stamina tubuh. Hal ini penting guna meminimalisir efek radikal bebas serta lebih tahan terhadap penyakit. Buah naga juga bermanfaat untuk mencegah dan mengatasi anemia. Dengan mengkonsumsi buah naga, dapat mencegah anemia buah naga kaya akan zat besi sebagai penyusun utama sel darah merah. Untuk menambah hemoglobin dalam darah, maka diperlukan makanan yang kaya akan zat besi. Dan hal ini bisa ditemukan pada buah naga. Buah Naga Merah memiliki kandungan vitamin B12 (riboflavin) yang sangat tinggi. Dalam tubuh sel darah merah (hemoglobin) sangat dibutuhkan. Dalam pembentukan sel darah merah dilakukan dengan bantuan dari vitamin B12 atau riboflavin. Sehingga konsumsi buah naga dapat membantu pembentukan sel darah merah (hemoglobin) dalam tubuh. Dengan rajin mengonsumsi buah Naga Merah secara teratur, maka anemia pada tubuh akan hilang dan produksi sel 
Jurnal Kesehatan Karya Husada, No 7 Vol 2 Tahun 2019

PISSN 2337649X/EISSN 2655-8874

Siti Mahmudah "Pemanfaatan Sirup Buah Naga Merah (Hylocereus Polyrhizus) Untuk Meningkatkan Kadar Hemoglobin" (hal 215-229)

darah merah akan kembali meningkat Untuk mendapatkan manfaat buah naga merah, maka buah ini sangat baik untuk dikonsumsi secara rutin. Kandungan di dalamnya terbukti mampu memperkuat sistem imunitas tubuh selain terdapat banyak kandungan vitamin lain di dalamnya. Sirup buah merupakan salah satu produk olahan cair yang dikonsumsi sebagian besar orang sebagai minuman minuman pelepas dahaga sekaligus sebagai obat dengan bahan herbal yang dapat mencegah dan mengobati penyakit (Rekomendasi WHO,2006). Sirup buah Naga Merah merupakan cara praktis dan mudah dalam mengkonsumsi buah Naga. Pemilihan buah Naga merah yang baik adalah buah yang warnanya merata dan tidak terdapat memar / bercak, pelepah masih utuh dan lentur, tekstur buah naga yang lunak menandakan buah sudah matang, dan mengeluarkan bau wangi yang khas. Proses pembuatan sirup dapat dilakukan dengan cara buah yang matang optimal disortasi kemudian dicuci dan dikupas. Pada saat pengupasan hanya diambil daging buahnya saja. Kemudian dihancurkan dan disaring. Ekstrak daribuah kemudian ditambahkan gula pasir dengan perbandingan $1: 0,5$ setelah itu dipanaskan sampai mengental kemudian dimasukkan ke dalam botol yang telah disterilkan. Berdasarkan hasil analisis statistik menggunakan uji Independent $T$ Test pada kelompok perlakuan dan kontrol didapatkan nilai $p$-value 0.034 $<0,05$ sehingga ada perbedaan yang signifkan antara rerata kadar Hemoglobin pada responden kelompok perlakuan dan pada kelompok kontrol. Dengan demikian terdapat perbedaan peningkatan kadar hemoglobin antara responden yang mengkonsumsi sirup buah

Naga Merah (Hylocereus Polyrhizus) dengan yang tidak mengkonsumsi. Konsumsi sirup buah Naga Merah 250 $\mathrm{ml} /$ hari selama 7 hari efektif untuk meningkatkan kadar Hemoglobin pada wanita pra lansia dan lansia dengan rerata peningkatan $1 \mathrm{mg} / \mathrm{dl}$. Pada kelompok kontrol yang tidak mengkonsumsi sirup buah Naga Merah terdapat penurunan kadar Hemoglobin dengan rerata 1,02 mg/dl. Pada responden kelompok perlakuan yang diberikan sirup buah Naga Merah dengan dosis $250 \mathrm{ml} /$ hari semua mengalami peningkatan kadar 
Jurnal Kesehatan Karya Husada, No 7 Vol 2 Tahun 2019

PISSN 2337649X/EISSN 2655-8874

Siti Mahmudah "Pemanfaatan Sirup Buah Naga Merah (Hylocereus Polyrhizus) Untuk Meningkatkan Kadar Hemoglobin" (hal 215-229)

Hemoglobin dengan rerata peningkatan 1 mg/dl sedangkan pada kelompok kontrol mayoritas turun dengan rerata penurunan $1,02 \mathrm{mg} / \mathrm{dl}$. Hal itu menunjukkan bahwa dengan mengkonsumsi sirup buah Naga Merah secara teratur dapat meningkatkan kadar Hemoglobin pada wanita pra lansia dan lansia. Buah Naga merah merupakan salah satu buah yang cukup mudah di dapatkan dan mempunyai banyak manfaat terutama untuk mencegah anemia yang sering terjadi pada wanita usia lanjut. Pada responden penelitian ini rerata kadar Hemoglobin pada kelompok perlakuan maupun kelompok kontrol sudah baik karena responden mempunyai kebiasaan mengkonsumsi sayuran hijau yang banyak mengandung zat besi dan banyak terdapat di lingkungan tempat tinggalnya yang merupakan wilayah pedesaan. Tanaman sayuran banyak dibudidayakan masyarakat setempat untuk konsumsi sehari-hari maupun untuk menambah penghasilan keluarga. Pencegahan anemia dapat dilakukan dengan mengonsumsi makanan yang mengandung zat besi dari bahan hewani (daging, ikan, ayam, hati, dan telur); dan dari bahan nabati (sayuran yang berwarna hijau tua, kacang-kacangan, dan tempe). Anemia bisa dicegah atau diatasi dengan cara- cara yang cukup sederhana, yaitu rajin mengkonsumsi makanan-makanan penambah darah. Salah satu makanan yang dapat meningkatkan jumlah sel darah dalam tubuh adalah buah-buahan. Buah memiliki sumber vitamin dan berbagai macam mineral yang baik untuk tubuh sebagai zat pengatur, vitamin dan mineral yang memiliki peranan yang penting untuk mengatur metabolisme tubuh, meningkatkan kinerja enzim dan hormon, serta berperan penting alam pembentukan sel dalam jaringan ubuh salah satunya adalah pembentuk sel darah merah. Buah Naga kaya akan kandungan gizi zat besi, sekitar $8 \%$ dari kebutuhan zat besi harian tubuh. Selain itu, buah Naga mempunyai banyak vitamin $\mathrm{C}$, zat yang meningkatkan kemampuan tubuh untuk menyerap zat besi lebih banyak dan Vitamin B12 (riboflavin) diperlukan oleh tubuh untuk membantu pembentukan sel darah merah. Oleh karena itu, mengonsumsi buah naga yang mengandung vitamin B12 tinggi, akan membantu mencegah terjadinya anemia atau penyakit kekurangan sel darah merah. 
Jurnal Kesehatan Karya Husada, No 7 Vol 2 Tahun 2019

PISSN 2337649X/EISSN 2655-8874

Siti Mahmudah "Pemanfaatan Sirup Buah Naga Merah (Hylocereus Polyrhizus) Untuk Meningkatkan Kadar Hemoglobin" (hal 215-229)

Warna merah pada buah naga mengkonsumsi sirup buah Naga menunjukkan tingginya kandungan Merah (Hylocereus Polyrhiruz)

betakaroten. Betakaroten merupakan nutrisi yang banyak terdapat pada tanaman yang memiliki warna mencolok. Buah naga memiliki peran penting dalam meningkatkan produksi sel darah merah di dalam tubuh. Zat besi yang ada pada buah naga sangat baik dalam meningkatkan kadar hemoglobin.

\section{SIMPULAN DAN SARAN}

\section{Simpulan}

a. Hasil penelitian pada responden wanita pra lansia dan lansia didapatkan rerata kadar Hemoglobin pre test pada kelompok perlakuan $12,04 \mathrm{mg} / \mathrm{dl}$ dan post test 13,04 mg/dl sedangkan pada kelompok kontrol rerata kadar asam urat pre test $13,31 \mathrm{mg} / \mathrm{dl}$ dan post test 12,29 $\mathrm{mg} / \mathrm{dl}$.

b. Uji Independent $T$ Test pada kelompok perlakuan dan kontrol didapatkan nilai p-values $0.034<$ Alpha 0,05 sehingga ada perbedaan antara responden yang selama 7 hari dengan yang tidak mengkonsumsi sirup buah Naga Merah (Hylocereus Polyrhiruz).

c. Konsumsi sirup buah Naga merah (Hylocereus Polyrhiruz) dengan dosis $250 \mathrm{mg} /$ hari selama 7 hari efektif untuk meningkatkan kadar Hemoglobin dengan rerata penurunan sebesar $1 \mathrm{mg} / \mathrm{dl}$. Pada kelompok kontrol yang tidak mengkonsumsi sirup buah Naga Merah (Hylocereus Polyrhiruz) terdapat penurunan kadar hemoglobin dengan rerata 1,02 $\mathrm{mg} / \mathrm{dl}$.

\section{Saran}

a. Masyarakat Untuk masyarakat khususnya ibuibu pra lansia dan lansia untuk dapat mengaplikasikan konsumsi buah Naga Merah (Hylocereus Polyrhiruz) sebagai salah satu metode alternatif untuk meningkatkan kadar Hemoglobin secara alamiah serta melakukan pemeriksaan kesehatan secara rutin.

b. Tenaga kesehatan Memberikan informasi kepada masyarakat tentang 
Jurnal Kesehatan Karya Husada, No 7 Vol 2 Tahun 2019

PISSN 2337649X/EISSN 2655-8874

Siti Mahmudah "Pemanfaatan Sirup Buah Naga Merah (Hylocereus Polyrhizus) Untuk Meningkatkan Kadar Hemoglobin" (hal 215-229)

manfaat buah Naga Merah

(Hylocereus Polyrhiruz) untuk

pengendalian kadar Hemoglobin

secara alamiah.

c. Peneliti selanjutnya. Hasil penelitian ini dapat dijadikan sebagai tambahan wawasan dan informasi untuk mengembangkan penelitian lebih lanjut tentang manfaat buah dan sayuran sebagai upaya pencegahan terjadinya anemia dan mengatasi sindrom penyakit gangguan metabolik pada lansia.

\section{DAFTAR PUSTAKA}

Agoes, Azwar. 2010. Tanaman Obat Indonesia. Jakarta: Salemba Medika.

Arisman. 2007. Gizi Dalam Daur Kehidupan. Jakarta: Buku Kedokteran

Arif Mansjoer. dkk, 2001. Kapita Selekta Kedokteran, Jakarta, Media Aes Cv Lapius FKUI.
Bakta, I. M. 2006. Anemia Defisiensi besi dalam Buku Ajar Ilmu Penyakit. Jakarta: FKUI

Fraser M. Diane, Cooper A. Margaret. Buku ajar bidan. Jakarta : EGC, 2009 https://id.wikipedia.org/wiki/A nemia

Kemenkes, 2017. Analisis Lansia di Indonesia.Pusat data dan informasi Kemenkes RI Jakarta

Kurniawan, Ani. 2002. Gizi Seimbang

Untuk Mencegah Hipertensi. Jakarta:

Direktorat Gizi Masyarakat

Tarwoto. 2007. Buku Saku Anemia Pada Ibu Hamil, Konsep dan Penatalaksanakannya. Jakarta: Trans Info Media.

Warisno, S danKres Dahana.2008. Buku Pintar Bertanam Buah Naga di Kebun, di Pot, dan di Pekarangan. Jakarta: PT Gramedia Pustaka Utama 